\title{
The Empirical Side of Law \& Economics
}

\author{
William M. Landes $\dagger$
}

When I joined the Law School faculty almost thirty years ago, I already had published several empirical papers on law and economics but I knew little law. I was hired as an economist. My friends were economists. My wife was an economist. I knew Richard Posner because of his enthusiasm for economics, but knew none of the other law professors at Chicago. Although my appointment continued the Law School's long tradition of having an economist on its faculty, the faculty and most law students had little interest in economics. Unlike other law schools, Chicago was not hostile to economics. But outside the field of antitrust law, most of its faculty believed that economics had little to contribute to understanding the law. This may surprise many readers because Ronald Coase had been a member of the Law School faculty since 1962 and had published his celebrated article The Problem of Social Cost in 1960. That article, which is the foundation of the modern application of economics to all fields of law, was cited by the Nobel committee in awarding Coase the Nobel Prize in economics in 1991.

Things are different today. Economics has become a central part of legal education, scholarship, and practice. All major law schools have one or more economists on their faculty; many young legal scholars have both law degrees and Ph.D.'s in economics (for example, three members of the Chicago Law School faculty have both law degrees and advanced degrees in economics); economic analysis of law is widely considered the most important development in legal thought in the last fifty years, ${ }^{2}$ economics has been systematically integrated into most areas of law, including even art law; and economic evidence has played an increasingly important role in the practice of law not only in antitrust but in contracts, intellectual property, securities, environmental law, and discrimination law. Other indicia of the growth of law and economics include the formation of The American Law and Economics Association in 1991, which now has more than one thousand

$\dagger$ Clifton R. Musser Professor of Law \& Economics at The University of Chicago Law School. I thank Elisabeth M. Landes for many helpful comments and suggestions.

See R.H. Coase, The Problem of Social Cost, 3 J L \& Econ 1 (1960).

2 See generally William M. Landes and Richard A. Posner, The Influence of Economics on Law: A Quantitative Study, 36 J L \& Econ 385 (1993), for an attempt to measure the importance of economics on legal scholarship. 
members, and the presence of five scholarly journals that specialize in economic analysis of law. Two of these journals are housed at the University of Chicago Law School: the Journal of Law and Economics (started in 1958 under the editorship of Aaron Director, an economist who had a Law School appointment) and the Journal of Legal Studies (started in 1972 under the editorship of Richard Posner). It should be noted, however, that the Journal of Law and Economics (JLE), notwithstanding its name, has become a journal that is edited by economic professors from the business school, and read mainly by economists, not lawyers. The JLE is widely regarded as one of the leading journals in the field of industrial organization, which focuses on the behavior of firms, industries, markets, and how laws and economic regulations affect the workings of the economic system. ${ }^{3}$ In contrast, the Journal of Legal Studies (JLS) appeals to both lawyers and economists and mainly publishes articles that use economic analysis to illuminate legal rules and doctrines. The JLS began as an interdisciplinary journal in the application of economics and other social sciences to legal studies, but over time evolved into the leading law and economics journal.

This Essay relates to a particular aspect of law and economics; namely, the use of empirical methods to study the law. I claim that empirical analysis plays a much smaller role in economic analysis of law than in economics in general. Moreover, I believe this can be explained on economic grounds. In the academic marketplace, scholars select research projects based on a comparison of returns and costs. It follows, therefore, that law and economics scholars are more likely to choose theoretical projects because they hold out the prospect of greater rewards and lower costs than empirical projects. ${ }^{4}$ Before con-

3 Although I have no direct empirical evidence on readership, data support the claim that the JLE is a leading economics journal (and, therefore, likely to be read mainly by economists). In one paper, the authors compiled a list of the twenty-seven leading scholarly journals in economics based on citation data from the Social Science Citation Index. See M.P. Burton and E. Phimister, Core Journals: A Reappraisal of the Diamond List, 105 Econ J 361, 366 Table 1 (1995). The JLE consistently ranks among the top ten economic journals using a variety of different citation measures. Id. In another study the authors include the JLE in the top half of the forty-two leading economic journals. See R. Pieters and H. Baumgartner, Who Talks to Whom? Intra- and Interdisciplinary Communication of Economic Journals, $40 \mathrm{~J}$ Econ Lit 483, 492-93 (2002). In neither study is the JLS listed or mentioned as an economics journal.

4 What constitutes "empirical work" is not self-evident in law and economics. It clearly includes presentation and analysis of data but arguably it might also include studies in positive law and economics that attempt to test models against legal rules that have developed from the outcome of hundreds or thousands of cases. In this Essay, I do not count as empirical-analysis articles those that have examined legal rules or precedents unless the authors have tabulated the outcomes of many cases. A good example of such empirical work would be Richard Posner's paper on negligence that examined a sample of more than 1,500 appellate decisions from 18751905 to test the consistency of the economic model of torts against actual case outcomes. Richard A. Posner, A Theory of Negligence, 1 J Legal Stud 29, 95 Table 14 (1972). A more recent example 
sidering why the returns are greater and costs lower for theoretical rather than empirical research in law and economics, I begin Part I appropriately with an empirical question: Does the evidence support the claim that there is relatively little empirical work in law and economics? I present data on the frequency of empirical articles in different subject matter areas of law and economics that have been published in the Journal of Legal Studies since its inception in 1972. My analysis focuses on the JLS because it is the leading law and economics journal, and, therefore, the types of articles it publishes should track the law and economics field in general. As a rough check, I also survey articles published in the American Law and Economics Review (ALER), which began publication in 1999 as the official journal of the association. Next I compare these results to articles published in the Journal of Law and Economics for the same time period. Because the JLE is a leading economic journal, the types of articles it publishes should be representative of the broad economic subject area of industrial organization. I also consider data on articles published in the Journal of Political Economy (JPE), which is among the most prestigious general-purpose economics journals. 'To anticipate my results, I found that the frequency of empirical articles that appear in the JLE (and JPE) is substantially greater than the number that appear in the JLS (or ALER). In Part II, I consider several reasons why there is relatively little empirical work in law and economics. Not surprisingly, these reasons reflect equilibrium outcomes in the market for legal scholarship in which both demand and supply factors influence the types of scholarship that are published.

\section{THE DATA}

My sample covers all articles published in the JLE and JLS during the period 1972 (the initial publication year of the JLS) to 2002. I classify articles by subject matter (for example, common law, procedure, industrial organization, and so forth) and by empirical content. I define an article as empirical if it analyzes data but not, as noted earlier, if it only examines legal doctrines or precedents without tabulating the results of cases. That is, I count as empirical an article that analyzes and tabulates the characteristics or outcomes from a relatively large sample of cases but not one that discusses some cases or presents anecdotal data or other evidence gleaned from a few cases. Al-

is William M. Landes and Richard A. Posner, Harmless Error, 30 J Legal Stud 161,181-92 (2001), which tests a formal model of harmless error against data from 963 appellate decisions in which the majority opinion discusses harmless error.

5 See Pieters and Baumgartner, $40 \mathrm{~J}$ Econ Lit at $492-93$ (cited in note 3); Burton and Phimister, 105 Econ J at 365-72 (cited in note 3). 
though the typical empirical article in the JLS and JLE begins with an economic model and then proceeds to test its hypotheses using multiple regression analysis, I also count as empirical any paper that presents and discusses a body of data even if no formal statistical tests are performed. I exclude from my sample articles that appeared in special or supplementary journal issues (typically conference volumes) because they are more likely to reflect the interests of the organizers of the conference than the general subject matter areas of law and economics. Table 1 summarizes the data.

TABLE 1

Articles Published in the Journal of Law \& Economics (JLE), Journal of Legal Studies (JLS), and American Law and Economics Review (ALER) ${ }^{6}$

\begin{tabular}{|c|c|c|c|c|c|c|c|c|c|}
\hline \multirow[b]{2}{*}{ Subject Matter } & \multicolumn{3}{|c|}{$\underline{\underline{\mathrm{JLE}}}$} & \multicolumn{3}{|c|}{$\underline{\underline{\mathrm{J}} S \underline{S}}$} & \multicolumn{3}{|c|}{ ALER } \\
\hline & Total & Emp & $\%$ & Total & Emp & $\%$ & Total & Emp & $\%$ \\
\hline All & 604 & 437 & 72.4 & 571 & 220 & 38.5 & 40 & 18 & 45.0 \\
\hline Ind.Org. & 292 & 235 & 80.5 & & & & & & \\
\hline Pub.Choice & 62 & 61 & 98.4 & 36 & 18 & 50.0 & & & \\
\hline JLS & 122 & 75 & 61.5 & & & & & & \\
\hline Common Law & & & & 163 & 34 & 20.9 & & & \\
\hline Crime & & & & 60 & 33 & 55.0 & & & \\
\hline Procedure & & & & 111 & 58 & 52.3 & & & \\
\hline
\end{tabular}

Table 1 indicates that of the 604 articles published in the JLE in the $1972-2002$ period, 437 , or 72 percent, were empirical. ${ }^{7}$ Over the same period, 220 , or about 39 percent of the 571 articles published in the JLS were empirical. ${ }^{8}$ In short, although both journals published

6 Brief descriptions of the subject matter categories are as follows: industrial organization (articles on economic regulation and behavior of economic markets), public choice (articles that focus on the political marketplace and collective decisionmaking from the perspective of selfinterested individuals), JLS (articles published in the JLE that fit the subject area of the JLS), common law (mainly articles in torts, contracts, and property), crime (articles on law enforcement and deterrence), and procedure (articles on legal decisionmaking, such as why cases settle and the impact on settlement of different procedural rules).

7 As a check on the claim that the JLE is primarily an economics journal that appeals to economists, I computed the percentage of empirical articles in the past twelve issues of the Journal of Political Economy, another prominent economics journal (from August 2000 to August 2002). Of the 96 articles in these twelve issues, 66 , or 69 percent, were empirical. This is about the same percentage as I found for the JLE.

8 The difference between the two journals in the average ratio of empirical articles is 
about the same number of articles during the past thirty years, the JLE (an economics journal) published twice as many empirical articles as did the JLS. The difference between the two journals is even greater when one looks at the major subject areas. Nearly 50 percent of JLE articles were in the field of industrial organization, and more than 80 percent of those articles involved empirical analysis. By contrast, economic analysis of the common law and procedure have been the two main subject matter areas of the JLS. About 30 percent of the articles in the combined fields ( 21 percent in the common law and 52 percent in procedure) employed empirical analysis.

Two other differences between the two journals are worth mentioning. One relates to the 122 articles in the JLE that overlap the subject matter area of the JLS. Typically, the subject matter of these articles concerned property rights, liability rules, and crime. More than 60 percent of the $122 \mathrm{JLE}$ articles used empirical analysis compared to 39 percent for the JLS, and this difference is statistically significant. The other difference is the public choice category in both journals. Within public choice, nearly 100 percent of JLE articles (61 of 62) used empirical analysis compared to 50 percent of the JLS articles (18 of 36). (Again, the difference between the two journals is statistically significant.) These two points taken together suggest that the higher frequency of empirical studies in the JLE does not simply reflect differences in subject matter because large differences occur within similar subject matter areas. ${ }^{10}$

Table 1 also includes information on articles published in the eight issues of the ALER (two per year starting in 1999). Of the 40 articles (excluding 9 survey articles and 3 presidential addresses), 18, or 45 percent, involved empirical analysis. This figure is slightly higher than 38.5 percent figure for the JLS but lower than the JLS over the past four years ( 41 of 74 articles, or 55 percent, were empirical from 1999-2002).

highly statistically significant (a t-statistic greater than seven).

9 The main reason why there is a greater fraction of empirical articles in the procedural category than the common law category for the JLS is probably that data are more readily available in the procedural category. Many procedural papers involve litigation models that can be tested against data from federal and state court agencies. In contrast, empirical analysis of common law subjects usually requires the researcher to collect data from cases because pre-existing data are not available.

10 The JLS is not exclusively a law and economics journal. It has on occasion published articles in legal history, jurisprudence, law and sociology, and law and political science. Since I did not distinguish these fields from law and economics, I may be biasing downward the fraction of empirical articles in law and economics. Although legal history and jurisprudence are unlikely to include empirical analysis, that is not true for the other two fields. Hence, it is unclear whether I have understated the relative importance of empirical analysis in law and economics by looking at all articles published in the JLS rather than just economic articles. 


\section{FIGURE 1}

The Proportion of Empirical Articles in the Journal of Law \& Economics, Journal of Legal Studies, and American Law and Economics Review: 1972-2002

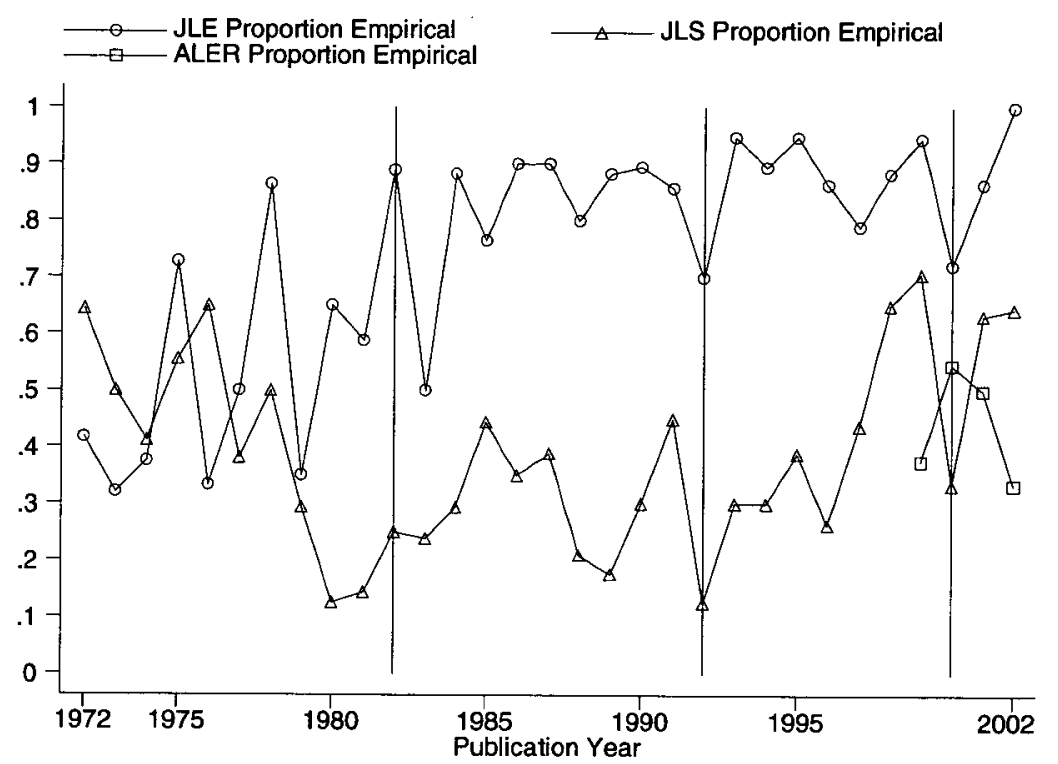

Figure 1 shows that the JLE has published a greater percentage of empirical articles than the JLS each year except for the first five years of publication of the JLS. I explore why the JLS published relatively more empirical articles in its early years and then reversed course, as well as other differences between the two journals in the regression analysis presented in Table 2.

Equation 2.1 indicates a statistically significant increase of about 2.7 percent per year in the fraction of empirical articles published in the JLE over the 1972 to 2002 period. In comparison, I find no significant time trend in empirical articles in the JLS (see equations 2.3-2.5), although Figure 1 and equation 2.5 suggest a significant increase of about 60 percent in the last six years for the JLS (the regression coefficient on the variable Dum97 equals .68 and is statistically significant). It is too early to tell, however, whether this reflects a permanent increase in the relative frequency of empirical articles in law and economics or a temporary though statistically significant upsurge. The low rate of empirical articles in the ALER (45 percent in the 1999 to 2002 period), however, suggests that the JLS increase since 1997 does not reflect a permanent increase in empirical analysis in law and economics.

How does one explain the changes that have occurred in the publication of empirical articles in the two journals? Two competing hypotheses are worth considering. One is that the fraction of empirical 
articles reflect changes in the underlying body of scholarship in a field. According to this view, journal editors are largely passive and apply roughly consistent standards to submissions. Hence, if scholars are shifting in the direction of more empirical work, journal publications will move in the same direction. The alternative hypothesis is that the types of articles published in a journal largely reflect the preferences of its editors. If, for example, the editor favors empirical over theoretical articles, he is likely to treat them more favorably in the review process. This in turn will lead to changes in the type of submissions that are more congruent with the editor's preferences. Ultimately, this will show up in a relative increase in the publication of empirical articles.

Consider the three vertical lines (at 1982, 1992, and 2000) in Figure 1, which denote changes in the editorship of the JLE and JLS. The year 1982 was both Ronald Coase's last year as editor of the JLE (more about this later) and Richard Posner's final year as editor of the JLS. Richard Epstein's editorship of the JLS commenced with the 1983 issue and continued through 1991. Geoffrey Miller became coeditor in 1990. I became co-editor with Miller (and later Mark Ramseyer and Eric Posner) for the 1992 to 2000 period. Richard Posner and I both separately and jointly have a long history of publishing empirical work in law and economics, and both of us sought to encourage empirical submissions during our tenure as editors of the JLS. This is not meant to imply that Epstein or Miller opposed empirical analysis, but rather that their positions were more neutral than either Posner's or mine. If an editor's preferences strongly matter, one would expect to find a higher frequency of empirical articles during Posner's and my tenure as editors compared to Epstein's or Miller's. The evidence in Table 2 does not support this hypothesis. In both equations (2.4) and (2.5), the regression coefficients on the Posner/Landes variable are negative and statistically insignificant (although the coefficient in equation (2.4) is marginally significant) indicating no increase (and possibly a decrease) in the fraction of empirical articles published in the JLS during Richard Posner's and my tenure as editors. In short, one cannot reject the hypothesis that the frequency of empirical articles in the JLS is independent of the preferences of its editors, suggesting that editors play a more passive than active role in selecting articles for publication. 
TABLE 2

Regression Analysis of Frequency of Empirical Articles

( $t$-statistics in parentheses)

\begin{tabular}{|c|c|c|c|c|c|}
\hline \multirow{3}{*}{$\begin{array}{l}\text { Independent } \\
\text { Variables }\end{array}$} & \multicolumn{5}{|c|}{ Logarithm Ratio of Empirical to Total Articles } \\
\hline & \multicolumn{2}{|c|}{$\frac{\text { J. Law \& Economics }}{\text { Eq }(2,2)}$} & \multicolumn{3}{|c|}{ J.Legal Studies } \\
\hline & Eq. (2.1) & Eq. (2.2) & Eq. (2.3) & Eq. (2.4) & Eq. (2.5) \\
\hline Year & $\begin{array}{c}.03 \\
(5.54)\end{array}$ & $\begin{array}{c}.02 \\
(2.02)\end{array}$ & $\begin{array}{c}.02 \\
(.91)\end{array}$ & $\begin{array}{c}.02 \\
(.67)\end{array}$ & $\begin{array}{l}.004 \\
(.30)\end{array}$ \\
\hline$\underline{\text { Coase }}$ & - & $\begin{array}{c}-.22 \\
(1.34)\end{array}$ & - & - & - \\
\hline$\underline{\text { Posner/Landes }}$ & - & - & - & $\begin{array}{c}-.43 \\
(1.75)\end{array}$ & $\begin{array}{c}-.21 \\
(1.43)\end{array}$ \\
\hline$\underline{\text { Dum77 }}$ & - & - & - & - & $\begin{array}{c}.80 \\
(3.06)\end{array}$ \\
\hline$\underline{\text { Dum97 }}$ & - & - & - & - & $\begin{array}{c}.68 \\
(2.65)\end{array}$ \\
\hline$\underline{\text { Constant }}$ & $\begin{array}{c}-54.9 \\
(5.57)\end{array}$ & $\begin{array}{c}-35.5 \\
(2.03)\end{array}$ & $\begin{array}{l}-32.4 \\
(.94)\end{array}$ & $\begin{array}{l}-32.4 \\
(.69)\end{array}$ & $\begin{array}{c}-10.22 \\
(.34)\end{array}$ \\
\hline Time Period & $1972-2002$ & $1972-2002$ & $1972-2002$ & 1972-2002 & 1972-2002 \\
\hline$\underline{\mathbf{R}^{2}}$ & .50 & .51 & 0 & .06 & .44 \\
\hline Durbin-Watson & 2.25 & 2,590 & 2.09 & 2.18 & 2.06 \\
\hline Observations & 31 & 31 & 30 & 30 & 31 \\
\hline \multicolumn{6}{|c|}{$\begin{array}{l}\text { Variable Definitions: Year }=\text { time trend variable; Coase takes the value } 1 \text { when Coase was } \\
\text { editor of the JLE in the years } 1972-82 \text { and } 0 \text { otherwise; Posner/Landes takes the value } 1 \text { in } \\
\text { the years } 1972-82 \text { and } 1992-2000 \text { when R. Posner or Landes were editors of JLS and } 0 \text { oth- } \\
\text { erwise; Dum77 takes the value } 1 \text { for the years } 1972-77 \text { and } 0 \text { otherwise; and Dum } 97 \text { takes the } \\
\text { value } 1 \text { for the years } 1997-2002 \text { and } 0 \text { otherwise. } \\
\text { Note: Equations (2.3) and (2.4) are corrected for first order autocorrelation using the Coch- } \\
\text { rane-Orcutt method. }\end{array}$} \\
\hline
\end{tabular}

It is worth repeating that Figure 1 shows that in its first five years, the JLS published relatively more empirical articles than the JLE (55 percent for the JLS and 43 percent for the JLE from 1972-77), but this number fell sharply during the next six years and remained in the range of 15 to 25 percent for most of the next fifteen years (when first Epstein and then I served as editor). This suggests that an editor's preferences can have a substantial impact on the type of papers pub- 
lished during the inaugural years of a journal, in part, because the editor must solicit papers for the new journal. As the journal becomes better known, the editor's influence will diminish and the journal's publications will largely reflect the overall interests of scholars working in the journal's fields rather than the editor's particular preferences. This is consistent with the results in equation (2.5) in which I added a variable to reflect the first six years of the Journal of Legal Studies (Dum77). The regression coefficient on Dum77 indicates a statistically significant higher rate of publication of empirical articles in the years 1972-77 compared to the next twenty years. To be sure, the editor still has a significant role to play in selecting which articles to publish, but after the journal's early years he is responding to, rather than determining, the types of articles submitted. Notice also that in equation (2.5), the Posner/Landes variable is statistically insignificant and the Dum97 variable is positive and statistically significant, reflecting the increase in the proportion of empirical articles in the JLS since 1997.

Consider now the Journal of Law and Economics. Shortly after I joined the Law School faculty in 1974, I became associate editor and then co-editor with Ronald Coase of the JLE. Coase had tremendous affection for the JLE and it was one of the main reasons he gave for remaining at the Law School through much of his later career. Coase also had strong views on economic research. He was not a big fan of formal mathematical and econometric models, nor of extending microeconomics into subject areas outside the traditional areas of economics. Coase hoped to use his editorship of the journal to encourage economists to study the actual workings of the economic system. Coase, however, was not optimistic. He stated, "My point of view has not in general commanded assent .... [M]ost economists have a different way of looking at economic problems and do not share my conception of the nature of our subject." ${ }^{, 12}$ Coase asked me to become an editor of the JLE precisely to help with the growing number of submissions that contained formal mathematical and statistical models. This is consistent with the hypothesis that though editors matter, they probably matter less than interests of scholars working in the fields that the journal seeks to publish. I tested the impact of Coase's editorship on the fraction of empirical articles in the JLE by adding a variable for the 1972 to 1982 period when Coase was editor of the JLE (see equation (2.2)). Since the JLE was already well-established by

11 As mentioned earlier, it is too soon to determine if the post-1997 increase reflects a long-run increase in empirical articles in law and economics.

12 R.H. Coase, The Firm, the Market and the Law 1 (Chicago 1988). 
1972 , it is not surprising that the regression coefficient on the Coase variable is statistically insignificant."

\section{A Simple Model OF LEGAL SCHOLARSHIP}

I now set out an economic model of legal scholarship to help explain why there is significantly less empirical work in the law and economics field than in economics generally. The results in Part I strongly suggest that the relative absence of empirical articles in law and economics reflects the kind of scholarship taking place in the field rather than the particular preferences of the editors of the JLS. Before setting out the economic model, however, I want to look more closely at the definition of empirical analysis used in this Essay.

Although conventional empirical analysis is neglected in law and economics, another kind of "empirical analysis" is not. The positive economic theory of law seeks to test the hypothesis that legal rules and doctrines, particularly common law rules, are best explained as efforts by judges to promote economic efficiency. The theory is often tested against a large number of legal rules and doctrines by asking whether they are consistent with the efficiency hypothesis. The principal "data" are legal doctrines and precedents that are the product of countless legal decisions. Evidence comes not from the systematic quantification of case characteristics and outcomes but from the study of legal rules themselves. My definition of empirical analysis, however, excludes such studies unless they also examine conventional data. If the study of legal rules and precedents were deemed empirical, my calculations clearly would understate the extent of empirical analysis in law and economics.

There are several reasons why I have not expanded the definition of empirical analysis to include articles on the positive economic analysis of law.

First, it would add a great deal of subjectivity to the definition of empirical. Would it mean that any article, for example, that discusses negligence or strict liability is empirical because these rules are the product of thousands of case outcomes? Or would it require something more - for example, a study designed to explain why some types of accidents are governed by strict liability and others by negligence?

13 I add that this test is at best a crude test of the hypothesis that the editor's preferences are less important than the type of work being done in the field. The specification of the dependent variable in Equation 2.2 would only roughly relate to the use of formal mathematical and statistical models in industrial organization.

14 It would also bias downward measures of empirical analysis in economics because I did not count as empirical an economic article that tests its predictions against a set of illustrations and facts that may be drawn from earlier data analysis or purport to be descriptions of actual marketplace behavior. 
Second, there is an important difference between conventional empirical analysis and positive law and economics that makes it questionable to call the latter empirical analysis. Legal rules and precedents are difficult to quantify for purposes of sampling and hypothesis testing. What would it mean, for example, to claim that 70 or 80 or 95 percent of tort rules are efficient? Rules differ in importance. The tort rule that entitles each dog to one bite (an oversimplification of the rule that liability for damage inflicted by domestic animals requires that the owner knew or had reason to know that the animal was dangerous) is probably less important than the doctrine of respondeat superior (which holds the employer liable for torts of his employees committed in furtherance of the employer's business). Suppose one rule promotes efficiency but the other does not. Should the rules be weighed equally in testing the efficiency theory of torts even though respondeat superior is likely to have more substantial consequences on behavior? ${ }^{15}$ Law and economics scholars attempt to meet this kind of objection by examining a large number of legal rules, which avoids the accusation that they have selected an unrepresentative sample to test the efficiency theory. Still, there is a problem in testing a theory against its conformity with a set of rules rather than its success in explaining easily quantifiable data.

A third difficulty in testing theory against legal rules is the danger of substituting rationalization for prediction and empirical verification. The positive economic theory of law looks for an efficiency explanation for legal rules. ${ }^{16}$ Often the theory has enough degrees of freedom that a clever researcher can construct an efficiency explanation for any rule, and if it still appears inefficient, he can bring in administrative or transaction costs to explain why an "inefficient" rule is really efficient. To be sure, positive law and economics does not have a monopoly on rationalization. Just as one may be clever enough to rationalize legal decisions in efficiency terms, data analysis is also subject to similar abuses. A clever researcher may be able to massage the data in ways to rationalize the predictions of an economic model or as

15 One could address this question imperfectly, for example, by counting cases that cite these doctrines. If that were done, I would have classified the article as an empirical study because it would have contained some data analysis (here of the number of cases).

16 This statement goes too far and often mischaracterizes positive law and economics. A researcher may start with a few simple legal rules, but the model may imply additional kinds of rules in particular circumstances. One then tests whether the model's predictions are confirmed by these other rules. Thus, in the area of torts, law and economics scholars may start off examining the efficiency implications of strict liability versus negligence but then extend this to a myriad of legal rules. See, for example, William M. Landes and Richard A. Posner, The Economic Structure of Tort Law (Harvard 1987), which applies the economic model to many subtle differences in legal rules. 
Ronald Coase once stated, "if you torture the data enough, nature will always confess." "17

Let us now turn to a position then, of legal scholarship. To simplify, assume that we can specify an index of the "price" per unit of legal scholarship and an index of the quantity or supply of qualityadjusted scholarship. Other things the same, scholars prefer to "sell" their scholarship at higher than lower prices. Higher prices will be associated with higher academic salaries, appointments at more prestigious institutions, higher consulting and lecture fees, and greater nonpecuniary benefits. Suppose a scholar faces a choice between undertaking a theoretical or empirical research project. Assume they are equally costly in terms of time and effort but the academic market attaches a higher value to theoretical than empirical work. Other things the same, a "rational" scholar will choose the theoretical over the empirical project. Of course, as more scholars shift from empirical to theoretical analysis, the returns to theory will fall relative to empirical work. An equilibrium distribution of research will be reached when the returns to both theoretical and empirical research are roughly equal. The contention of the Essay is that both demand and supply factors work to reduce the production of empirical scholarship in law and economics.

\section{A. The Supply of Legal Scholarship}

Consider first the supply side. The more costly it is to produce empirical scholarship, the further to the left will be the supply curvein other words, fewer empirical articles will be produced at each "price." There are several reasons why the cost of producing empirical articles in law and economics is likely to be significantly higher than that of theoretical articles. First, many law and economics scholars were trained as lawyers not economists. They are "self-taught" economists who have been able to pick up a basic understanding of microeconomics and apply its principles to legal problems. Until recently, this has involved a modest investment of time and effort with a big academic payoff. Today, the costs are somewhat greater because economics has become increasingly mathematical, and game theory has become part of the basic tools of microeconomics. In contrast, the cost involved in acquiring empirical skills is much more substantial. Typically, these skills are acquired over several years in the course of writing a dissertation in economics. Unless the returns from empirical scholarship in law and economics are substantially greater than the returns from theoretical work, lawyers are unlikely to invest the addi-

17 R.H. Coase, How Should Economists Choose? 16 (AEI 1982) (originally stated at a talk Coase gave at the University of Virginia in the early 1960s). 
tional time and effort in developing empirical skills. Because of the high cost of acquiring empirical skills, it would be rational for the scholar trained as a lawyer to choose theoretical over empirical research projects, or, alternatively, if he chooses an empirical project to team up with an economist or other scholar trained in empirical analysis. This suggests further that since economists have a comparative cost advantage in analyzing data, most empirical work in law and economics will be undertaken by persons with a doctorate in economics or, in the case of joint work, where one of the authors has a doctorate in economics.

The difficulty with the hypothesis, however, is that it leaves unexplained why many economists (without law degrees) who are currently on law school faculties (for example, Steven M. Shavell at Harvard, A. Mitchell Polinsky at Stanford, Robert D. Cooter at Berkeley, Alvin K. Klevorick at Yale, David D. Haddock at Northwestern, and Victor P. Goldberg at Columbia) also have done very little empirical research and why law professors with joint degrees (a law degree and a doctorate in economics) have with a few exceptions also steered away from empirical work. ${ }^{18}$ Although I believe that demand factors play an important role here, cost factors are also at work. Because law and economics scholarship is largely centered at law schools and not economic departments, the cost of undertaking empirical projects tends to be greater. Graduate programs in economics produce students looking for dissertation topics. Students are more likely to find topics if they work as research assistants or even collaborate on projects with their professors. Relatively easy access to graduate students tends to lower the cost of empirical research. In contrast, law schools are professional schools that train students to practice law. Although law students are delighted to work as research assistants, they do not possess empirical skills, nor are they around the school for a long enough period to make it worthwhile for them to acquire these skills. In short, the absence of graduate students tends to raise the cost of conducting empirical research at law schools. This may help explain why many economists at law schools have focused more on theoretical than empirical research. ${ }^{19}$

18 There are several important exceptions: John Donohue of Stanford Law School and Ian Ayres of Yale Law School have joint degrees and have made major empirical contributions, and the economist Kip Viscusi of Harvard Law School has published numerous empirical papers in the fields of industrial organization and law and economics.

19 One might respond, however, that it cannot be that costly for a law school faculty member to hire graduate students in economics as research assistants. The extra transaction costs would seem to be modest. Indeed, Posner and I have hired graduate students in economics. There is another cost disadvantage. An economics graduate student will probably learn more from working with an economics professor, and the economics professor is likely to be more helpful in getting the student a teaching job. Given that many graduate students have fellow- 
A final supply consideration is the lack of data in law and economics compared to economics in general. To be sure, a great deal of data are available on crime, prisons, and litigation that have been collected by government agencies. In contrast, empirical research in common law areas tends to be more costly in terms of time because it involves assembling and collecting data from original sources. Not surprisingly, I noted earlier that the percentage of empirical studies in crime and litigation in Table 1 is substantially greater than in common law areas - for example, over 50 percent in both crime and litigation compared to about 20 percent in common law subjects. Put differently, cost differences probably result in relatively more empirical articles in crime and procedure than in common law subjects.

\section{B. The Demand for Legal Scholarship}

The intellectual traits most prized at law schools are verbal quickness and agility, crisp thinking, penetrating insights, and mastery of legal doctrines. In considering an appointments candidate many years ago, Richard Posner summed up this set of skills with the term "shimmering brilliance." In comparison, empirical work does not occupy an exalted place at law schools. It would only be a modest exaggeration to say that most law professors regard empirical work as a form of drudgery not worthy of first-class minds. In the legal academic pecking order, empirical research does not rank as high as theory. This translates into a downward shift in the demand for empirical relative to theoretical scholarship in law and economics. Hence, even if cost or supply conditions were identical for empirical and theoretical work (which they are not), demand consideration alone would lead to relatively more theoretical than empirical scholarship.

The Law School culture that exalts theory over empirical analysis has rubbed off on economists (and joint degrees) who have appointments at law schools. Their academic reputation and advancement has depended more on publishing theoretical papers that offer insights into legal doctrines rather than on careful empirical studies. Thus, demand factors tend to reinforce supply factors leading to relatively little empirical work in law and economics compared to the more traditional areas of economics. Demand considerations also suggest that economists at law schools are less likely to do empirical work than economists in economics departments who work in the law and economics field. The latter group (which includes Steve Levitt at Chicago, and Edward Glaeser and Andrei Shleifer at Harvard) will be more influenced by an academic tradition that highly values empirical work. 